\title{
Foreign Direct Investment (FDI) in Bangladesh: Prospects and Challenges and Its Impact on Economy
}

\author{
K. M. Anwarul Islam
}

Senior Lecturer, Department of Business Administration, The Millennium University, BANGLADESH

\begin{abstract}
This research will try to examine the FDI plays a dominant role in the economy of Bangladesh through accelerating Gross Domestic Product (GDP), export and domestic investment followed by overall economic growth. So it is vital for a developing country like Bangladesh to carry out effective measures in protecting the prospective foreign investors so that they can get a congenial atmosphere to invest their capital. They should feel that their role in the business arena of Bangladesh is respectfully valued. In this connection, friendly regulations, simplifying regulatory practices, investment incentives and removal of inefficient bureaucratic procedures should be ensured.
\end{abstract}

Keywords: Foreign Direct Investment, Economic Growth, Prospects \& Problems of FDI, Impact of FDI. JEL Classification Code: A10, E20, E22, E62

\section{INTRODUCTION}

$\mathrm{F}$ Toreign Direct Investment (FDI) is considered as one of the vital ingredients for overall development process of a developing country like Bangladesh. Industrial development is an important prerequisite for economic growth of a developing country. Bangladesh is basically a country of agrarian economy. For her economic development, industrial economy is imperative. So Bangladesh is gradually moving from agrarian economy to industrial economy. In the age of globalization, it has become a burning issue to exchange views, ideas, capital and human resources. Government of Bangladesh is trying to create a favorable investment environment through introducing economic policies, incentives for investors, promoting privatization and so on. Therefore, the contribution of FDI is necessary in the enhancement of a country's economic growth.

Researchers have marked FDI as an important factor in accelerating economic success and wealth of a country as well as a door in creating jobs, facilitating economy, and creating more competitive environment and contributing productivity to the host country.

In Bangladesh, FDI plays a significant role in GDP acceleration and economic growth (Mottaleb 2007). FDI has an unmentionable role in the modernization of the Bangladesh economy for last two decades. It helps the country in building up infrastructure, creating more employment, developing capacity, enhancing skills of the labor force of the host country through transferring technological knowledge and managerial capability, and helping in integrating domestic economy and the global economy. Various positive attributes of Bangladesh is now drawing the attention of the investors from both developed and developing countries. In Bangladesh, it is available to get skilled labor at relatively low wages. Moreover, there is reasonably stable macroeconomic environment. These two important factors can make Bangladesh an alluring destination for foreign investors. Lowest wage rates among the Asian countries, tolerable inflation rate, reasonably stable (except previous year) exchange rate, investment friendly custom regulations and attractive incentive packages make Bangladesh a favorable investment destination. Bangladesh became more open toward FDI policies over the last decades. These above features will certainly maintain the recent advancement in FDI investment in Bangladesh by the foreign investors.

During 1980s, FDI to Bangladesh was very little and mostly focused in banking and a few other sectors. Bangladesh started attracting FDI since 1996 in energy and power sector because of favorable and supportive policies for foreign investment, economic reform as well as unexplored gas and oil resources. In 1972, annual FDI inflow was 0.09 million USD and in 1996, it became 231.61 million USD which rose significantly in 2008 to 1086 million USD which declined to 913.32 million USD in 2010 (source: Bangladesh Board of Investment).

The objectives of this research paper are as follows:

- To evaluate the FDI status in Bangladesh.

- To find out the prospects \& problems of FDI in Bangladesh.

- To analyze the impact of FDI inflow on GDP, Export and private investment of Bangladesh.

\section{Methodology}

The methodology includes an econometric model as well as simple statistical tools such as mean, standard 
Asian Business Review, Volume 4, Number 1/2014 (Issue 7)

ISSN 2304-2613 (Print); ISSN 2305-8730 (Online)

deviation and percentage. This paper is fully based on secondary information. The relevant secondary data are collected from Statistics Department and Research Department of Bangladesh Bank (Central Bank of Bangladesh), Board of Investment, Bangladesh, Bangladesh Bank Bulletin, Economic Trend, Bangladesh Economic Review, World Investment Report 2010 published by UNCTAD, etc.

Time Reference

The time reference of the study will be 1996-2010.

Data Analysis

The statistical tools that have been used in the study areTrend analysis: For trend analysis, time series analysis has been used.

Standard deviation has been used for measuring dispersion from the mean result.

Regression is used to identify the relationship among the variables.

\section{Key Definitions}

\section{Foreign Direct Investment (FDI)}

FDI is an important category of international investment that shows a long-term relationship between the direct investor and the enterprise. It indicates the influence of the investor on the management of the enterprise. Direct investment relates the initial transaction between the investor and the enterprise. It also shows the transactions between them and among affiliated enterprises, both incorporated and unincorporated. The components of FDI are a) Equity capital, b) Reinvested earnings and c) Intra-company loans.

Equity Capital states the ownership as well as the share purchasing of an enterprise by a foreign investor. Reinvested earnings demonstrate that portion of earning of an investor which is not distributed back to him. This means the profits that are not given out as dividends. It is kept within the firm. Intra-company loans include debt transactions and these transactions are regarding lending by the foreign parent company to its affiliates in the form of both short and long-term.

\section{Economic Growth}

Economic growth is a rise in national or per capita income of an economy. If a country increases its production of goods and services, by whatever ways and becomes able to increase its average income, it can be mentioned that the country has achieved "economic growth". Economic growth can be measured in nominal terms. This includes inflation, or in real terms that is adjusted for inflation. GDP or GNP per capita is used in comparing the economic growth of one country's to another.

\section{FDI and Growth}

It is revealed in review of various literatures available on FDI that foreign investment is still viewed as a matter of debate. Opinions are still divided in deciding that whether FDI is boom or bane for host countries economic growth and development. FDI has its own merits and demerits.

Many scholars argue that developed nations may try to invade the sovereignty of host country through FDI. In order to earn quick profit they may exploit the natural resources at the faster rate and thus leave the host country deprived in the long run. It have been feared that FDI is a big threat to survival of domestic players. Again, many are of the opinion that basic objective of foreign investments is to earn profits by ignoring the overall social \& economic development of the host nation.

\section{Literature ReVIeW}

There is the global race for attracting FDI, but how much it can contribute to host country's economic development is a matter of assessment. Aitken and Harrison (1999) have evaluated the contribution of FDI to domestic productivity and found positive impacts of FDI on economic development. Again, Levine et al. (2000) found negative results on economic development.

Rothgeb (1984) found an immediate troublesome effect of FDI flows on developing countries. This effect would overcome after a short period of time, with positive impacts on growth. Rothgeb (1984) used his model to explore the impact of foreign investment on the growth of Bangladesh and found that FDI has a positive impact on growth. He also found a strong positive effect of the change in the level of domestic investment on growth.

V.N. Balasubramanyam, M. Salisu, and D. Sapsford (1996) did an examination about the impact of FDI on economic growth in developing economies using ordinary least squares. Applying the export promotion strategy, they found positive and significant impact of FDI on economic growth in developing countries. Simultaneously, it also showed that such relations do not exist in developing countries applying the import substitution strategy. Bengoa and Sanchez-Robles (1997) showed the positive correlation between FDI and economic growth. In this connection, with a view to getting benefit from long term FDI inflows, human capital, stable economic condition and liberalized markets are required in host countries. Borenszteina et al (1998) examined the data on FDI inflows of sixty nine developing countries by regression framework and found the importance of FDI as a means of transferring technology that contributes more to growth than domestic investment. Pattama (1999) analyzed the long run relationship between FDI and domestic investment in case of Thailand. He found that FDI has a significant and positive long term effect on domestic investment in Thailand. Despite this positive link between FDI and economic growth, empirical evidence also reveals negative association between them. This view goes to the dependency theorists who are in the opinion that dependence on foreign investment tends to create a negative impact on economic growth and income distribution.

The dependency theories argue that foreign gigantic players may create negative effect on the growth and development of domestic firms' of a host country in the 
long-run as they have large volume of capital, superior technologies, higher market access, advanced marketing networks and better managerial and human relation skills (Marksun \& Venables 1997, Agosin \& Mayer 2000, Kumar \& Pradhan 2002). According to the dependency theories, FDI may have an adverse impact on income distribution, employment, national sovereignty and autonomy of a country (Musila and Sigue 2006).

Bogahawatte (2004) examined the relationship between FDI and economic growth of Sri Lanka for the period of 1977 to 2003 by analyzing the relationship between real GDP, FDI Inflow, domestic investment and openness of the trade policy regime. The examination revealed a strong influence of FDI on economic growth. Mottaleb (2007) studied the determinants of FDI and its effect on economic growth in developing countries. He studied panel data of FDI flows of sixty low income and lower-middle income countries and found that FDI has an important effect on economic growth of third world countries by creating bridge between the gap of domestic savings and investment and familiarizing the up to date technology and management skill from developed countries.

Jung Wan Lee, Gulzada S Baimukhamedova, Sharzada Akhmetova (2008) analyzed the correlation between FDI inflows, exchange rate, and economic growth of Kazakhstan by a multivariate regression model with weighted least squares estimates. The results revealed the minimum significant impact of FDI on GDP growth of Kazakhstan. Abdul Rehman, Orangzab, Ali Raza (2009) conducted an analysis by using the data collected over the period of 1975-2008 and identified the determinants of FDI and its impact on GDP growth in Pakistan through different statistical tests and found positively significant impact of FDI on GDP growth of Pakistan. Furthermore, these results indicate that market size, trade openness / access to international market and quality of labor are the major determinants that have significant effect on the FDI inflow. The study also found no effect of market potential and communication facility on the attraction of FDI inflow in Pakistan.

Quader, Syed Manzur (2009) applied extreme bounds analysis to the data of the various catalyst variables of FDI inflows in Bangladesh. They found FDI and domestic investment have a positive effect on economic growth.

Piotr Misztal (2010) examined the influence of FDI on the economic growth in the Romania in period of 2000-2009 using the Vector Autoregression Model (VAR) and found linear relationship between FDI and economic growth.

Muhammad Azam (2010) examined the impacts of exports and FDI on economic growth of South Asian countries namely Bangladesh, India, Pakistan and Sri Lanka with simple log linear regression model using secondary data ranging from 1980 to 2009 and found that due to promotion of exports, economic growth of each country would increase. He also found FDI as positively significant at $1 \%$ level of significance for Bangladesh and
Pakistan, while for India it's insignificant and in case of Sri Lanka though it is significant but with unexpected negative sign.

\section{AN OVERVIEW OF FDI IN BANGLADESH}

\subsection{Present FDI Status}

Bangladesh has attracted USD 913 million foreign direct investments (FDI) in 2010 calendar year, a leap by 30 per cent. This upgrades the country's position to 114 from 119 out of 141 nations in the World Investment Report (WIR). During this period the telecom sector received USD 360 million FDI, the manufacturing sector received USD 238 million in investment from abroad, USD 145 million in the textile and clothing sector, while leather and leather products got USD 46 million. (The financial Express, 27 July, 2011)

As a developing country, Bangladesh needs Foreign Direct Investment (FDI) for its ongoing development process. Since independence, Bangladesh is trying to be a suitable country for FDI. In order to accelerate economic growth, Bangladesh opened her economy in the late 1980s to reap the benefits of FDI. In 1989 the government set up Board of Investment (BOI). The primary objective of which is aimed at attracting and facilitating investment from abroad (Mondal 2003). The government also lifted restrictions on capital and profit repatriation gradually and opened up almost all industrial sectors for foreigners to invest either independently or jointly with the local partners. Further, the government also introduced various financial and non-financial incentives like tax exemptions for power generations, import duty exemptions for export processing industries, tax holiday schemes for undertaking investment in priority sectors and low development areas, zero duty rate for the import of capital machinery and spare parts for 100 percent export oriented industries, almost no restrictions on the entry and exit mode, and reduction of bureaucratic hassles in getting faster approvals of foreign projects. Together with all these incentives followed by a low labor cost structure, Bangladesh has been an attractive destination for FDI in the South Asian region since the late 1980s.

The trend of Inflow of FDI in Bangladesh has increased over the 1980s as compared to earlier periods and this same momentum continues in 1990s as well. The total inflow of FDI has been increasing over the years. During the period of 1977-2010, total inflows of FDI were USD 8927.9 million, among which the total inflows of FDI during 2006-2010 was USD 4158.63 million. In 1977, this inflow was USD 7 million and in 2008, annual FDI reached to USD 1086.31 million. Unfortunately, there was a declination in inflows of FDI in 2010 which was USD 913.32 million (Source: Survey Report, Statistics Department, Bangladesh Bank). 
Asian Business Review, Volume 4, Number 1/2014 (Issue 7)

ISSN 2304-2613 (Print); ISSN 2305-8730 (Online)

Figure 1 illustrates the trend of FDI inflows in Bangladesh during 1996-2010.

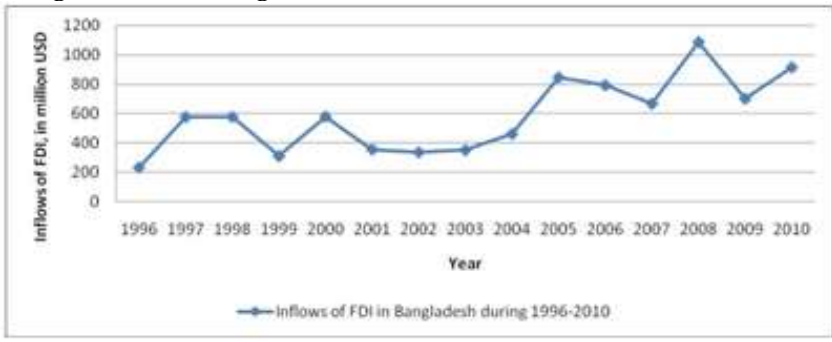

Figure 1: FDI Inflows in USD in Bangladesh during 19962010

Source: Survey Report, Statistics Department of Bangladesh Bank and Foreign Direct Investment in Bangladesh (1971-2010), Board of Investment.

The Figure 1 shows an inconsistent proceeding of FDI inflows during the period. In 1999 there was a sudden decline in the FDI and the falling trend continued for many reasons again in 2001, 2002 and 2003. Serious political unrest during the period discouraged foreign investment and it took quite some time to regain the confidence of foreign investors. There were also some other factors that force this declination in the inflows. After that, there was very good news for Bangladesh. The FDI inflow was on the steady rise from 2003 to 2005. It rose to US\$ 1086.3 million in 2008 but slumped to US\$ 700.16 in 2009 and again increased to $\$ 913.32$.

\subsection{FDI Inflows by Components}

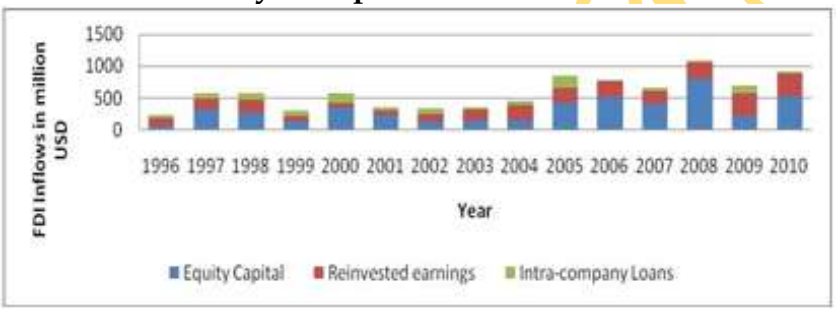

Figure 2: FDI Inflows (in million USD) by components in Bangladesh during 1996-2010

Source: Survey Report, Statistics Department of Bangladesh Bank and Foreign Direct Investment in Bangladesh (1971-2010), Board of Investment.

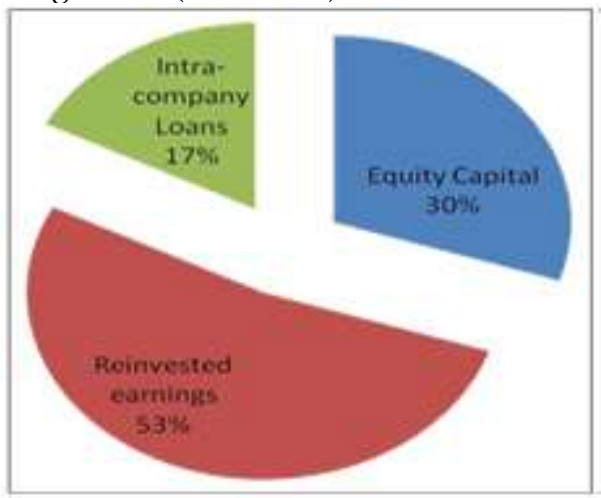

Figure 3 FDI Inflows, in million USD by components in 1996

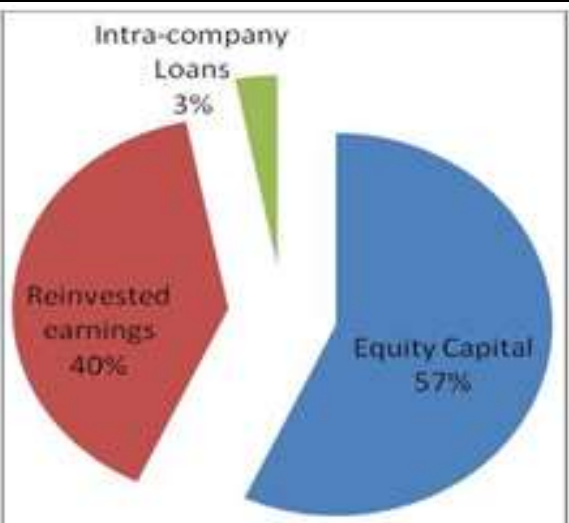

Figure 4 FDI Inflows, in million USD by components in 2010

Source: Survey Report, Statistics Department of Bangladesh Bank and Foreign Direct Investment in Bangladesh (1971-2010), Board of Investment.

FDI in Bangladesh consists of three components: Equity capital, Reinvested Earnings and Intra-company loans. These components have fluctuated considerably in the last two decades. In the early year of 1996, the total FDI inflow was only 210 million USD where reinvested earnings were the bigger portion. This trend continued up to 1998. Then there is a sudden decline in terms of total inflow as well as component wise inflow of FDI. Beside a slight increase in 2000, this declining trend continues up to 2003. After then total inflow continues to rise with some ups and downs. The portion of equity capita 1 continues to have a bigger part in the total FDI inflows. In 2008 the total inflows was 1100 million USD which is the highest ever. The shifting of component wise FDI inflow in Bangladesh is clearly in the Figure 3 and 4 . In present years, the major share of FDI inflow in Bangladesh come in equity capital from. In 1996 the share of equity capital in total FDI was 30 percent which increases to 57 percent in 2010. In 1996 share of reinvested earnings was 53 percent which decreased to 40 percent in 2010. On the other hand, share of intra-company loan was 17 percent which then decreased to 3 percent in 2010. This shows that the net transfer of resources from abroad into Bangladesh is fairly negligible. The contribution of FDI is very little in case of transfer of 'hardware' technology.

\subsection{FDI Inflows by Areas (EPZ and non EPZ)}

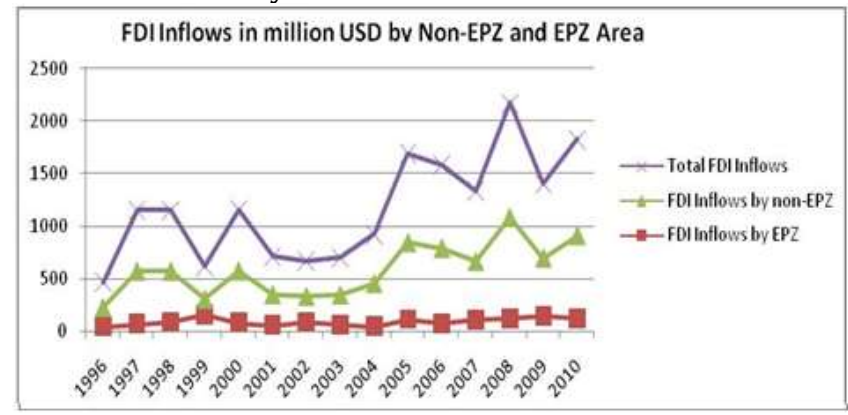

Figure 5: FDI Inflows (in million USD) by area (EPZ and non EPZ) in Bangladesh during 1996-2010 
Source: Survey Report, Statistics Department of Bangladesh Bank and Foreign Direct Investment in Bangladesh (1971-2010), Board of Investment.

Figure 5 reveals that despite the initial increase and steady continuation, FDI inflows in Non-EPZ areas was in declining trend during the period of 2001-2003. In 2004 it increased to 800 million USD and this trend continued up to 2005.The FDI inflows in Non-EPZ areas in 2010 recorded to USD 795.15 million which is 87 percent of total inflows whereas in the beginning of this period (in 1996) it was USD 189.3 million which is 82 percent of total inflows. In the EPZ areas, the FDI inflows were always in a steady direction.

\subsection{FDI Inflows by Sectors}

Sector-wise analysis of FDI reveals the fact that a shift has been made by the foreign investors in their investment in Bangladesh (Annex Table-3.4). The table shows the trend of FDI towards power and energy, manufacturing and telecommunications, whereas the neglected sectors were agricultural, Services and trade and commerce. In 2005, the main focus of investment was in the manufacturing sector. The success in textiles through the ready-made garments (RMG) industry was a vital part of this investment. The pie chart shows the shift of FDI in the sectors in Bangladesh. The pie chart draws a clear picture how the dimensions of FDI inflows have changed in recent years. The reduction in FDI shares of manufacturing demonstrates that its stronghold position for foreign investment is in declining state. On the other hand, telecom sector is gaining prominence during present years. In 2008 the telecommunications sector overtook manufacturing sector as the leading recipient of FDI. Due to increased privatization efforts by the government, telecom has emerged as one of the fastest growing sectors in the Bangladesh economy. Much of this can be explained by the increased competition between large private corporations that have magnified efforts to attract FDI and attain better and latest technology to optimize the profits. In addition to that, the energy sector draws lower amount of FDI, which is explained by the country's natural gas reserves. Another factor is the country's difficulty in electricity generation. The lack of production capacity forces the government to frequently 'load shedding' power. It imposes blackouts in areas of low power usage to meet the needs of areas of higher power usage. The government's lacking of the capital and liquidity of building power grids and expanding the country's electric capacity opens the door of much scope for foreign investment.

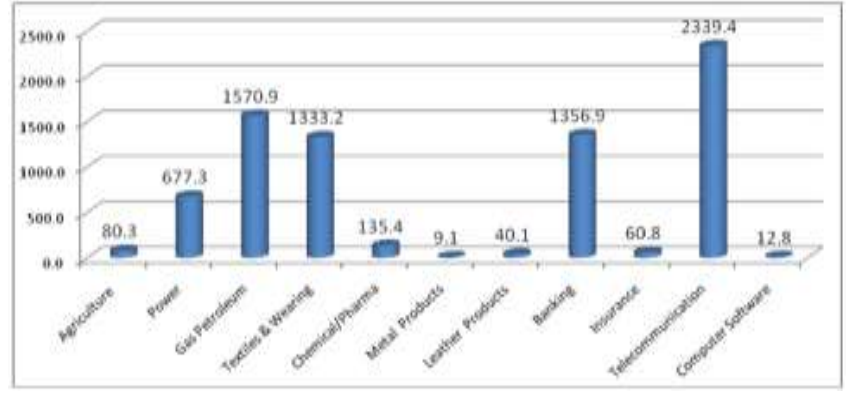

Copyright @ 2014, Asian Business Consortium | ABR
Figure 6: FDI Inflows (in million USD) by sectors in Bangladesh during 1996-2010.

Source: Survey Report, Statistics Department of Bangladesh Bank and Foreign Direct Investment in Bangladesh (1971-2010), Board of Investment.

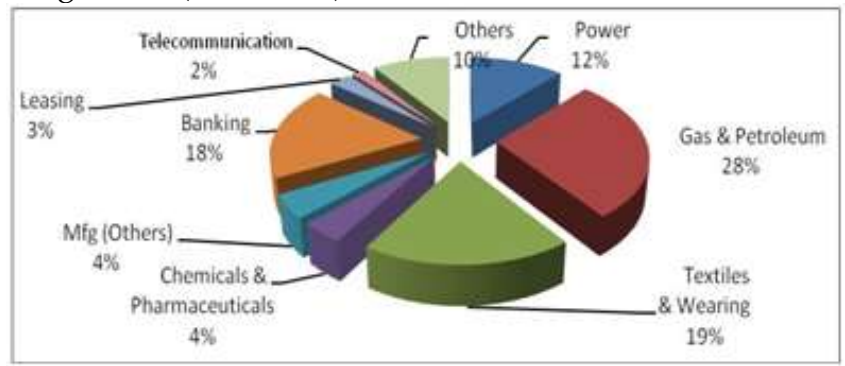

Figure 7: FDI Inflows (in million USD) by sectors in Bangladesh during 1996-2000.

Source: Survey Report, Statistics Department of Bangladesh Bank and Foreign Direct Investment in Bangladesh (1971-2010), Board of Investment.

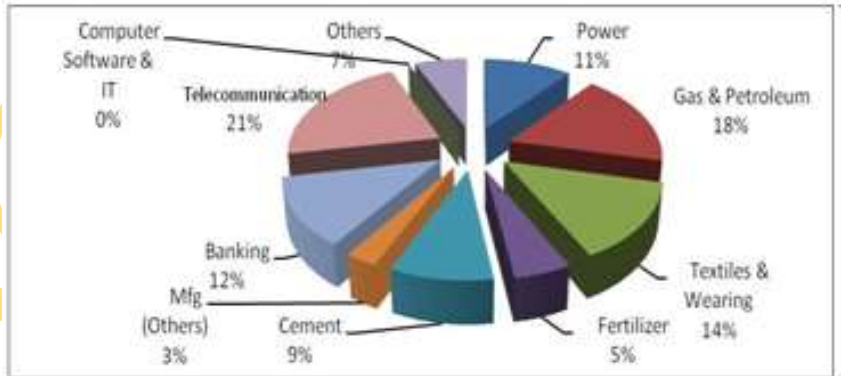

Figure 8: FDI Inflows (in million USD) by sectors in Bangladesh during 2001-2005.

Source: Survey Report, Statistics Department of Bangladesh Bank and Foreign Direct Investment in Bangladesh (1971-2010), Board of Investment.

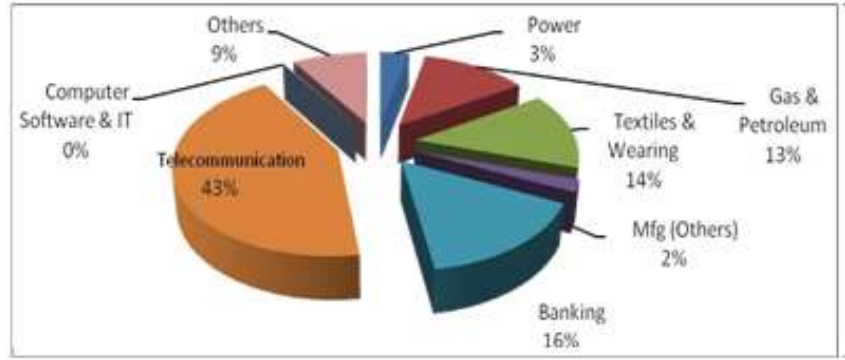

Figure 9: FDI Inflows (in million USD) by sectors in Bangladesh during 2006-2010.

Source: Survey Report, Statistics Department of Bangladesh Bank and Foreign Direct Investment in Bangladesh (1971-2010), Board of Investment.

In the Figure 8 and 3.4.4, it is clearly shown that the percentage of investment in various sectors has changed quite a lot. The percentage of telecommunication investment was $2 \%$ in $1996-2000$ was only $2 \%$, which increases to $21 \%$ during 2001-2005 and finally it topped to $43 \%$ during $2006-2010$. On the other hand, the portion of investment in the gas \& petroleum sector has declined gradually during the year of 1996 to 2010 . It was $28 \%$ in $1996-2000,18 \%$ in $2001-2005$ and only $13 \%$ in $2006-2010$. 
It is also a matter of great concern that the investment in energy sector has decreased from $12 \%$ to only $3 \%$, which is very alarming. The government should take a close look in this matter and take necessary steps to identify the causing factors and to rectify those to improve our present energy sector conditions.

\subsection{FDI Inflows by Countries}

The country wise FDI inflows in Bangladesh from top 10 investing countries during 1996-2010 are presented in Figure 10.

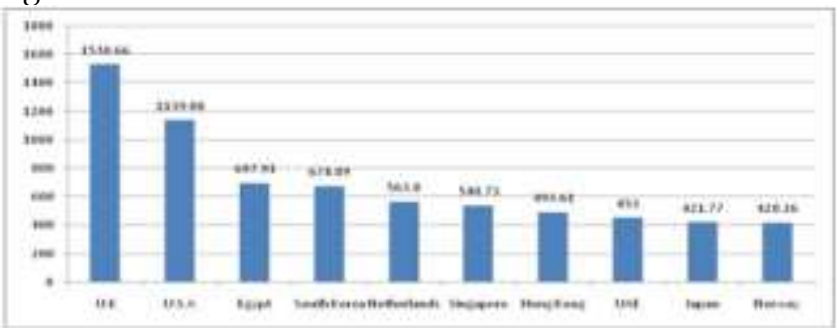

Figure 10: FDI Inflows (in million USD) by countries during 1996-2010.

Source: Board of Investment, Bangladesh.

The Figure 10 shows that United Kingdom has gained the top most position among the top 10 investing countries in Bangladesh during 1996-2010 in investing in various sectors of economy. Out of total FDI inflows from the top 10 investing countries during this period, $17.4 \%$ was from United Kingdom, 13\% from USA, 8\% from Egypt, 7.7\% from South Korea, $6.4 \%$ from Netherlands, $6.2 \%$ from Singapore, 5.6\% from Hong Kong, 5.2\% UAE, 4.8\% from Japan, 3.5\% from Malaysia, 3.2\% from Australia, 2.1\% from Denmark, 2.1\% from Switzerland.

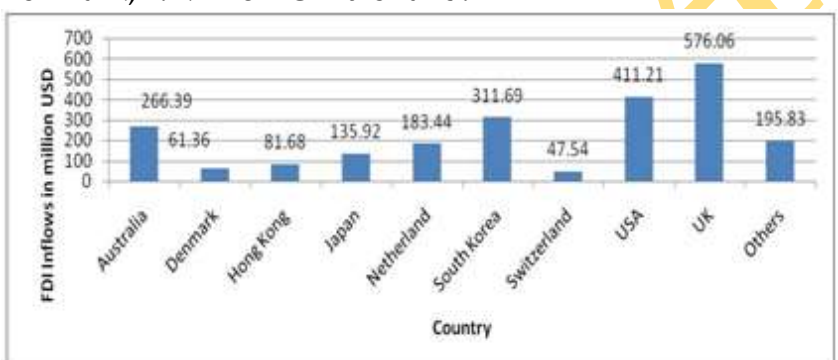

Figure 11: FDI Inflows (in million USD) by countries during 1996-2000.

Source: Survey Report, Statistics Department of Bangladesh Bank and Foreign Direct Investment in Bangladesh (1971-2010), Board of Investment.

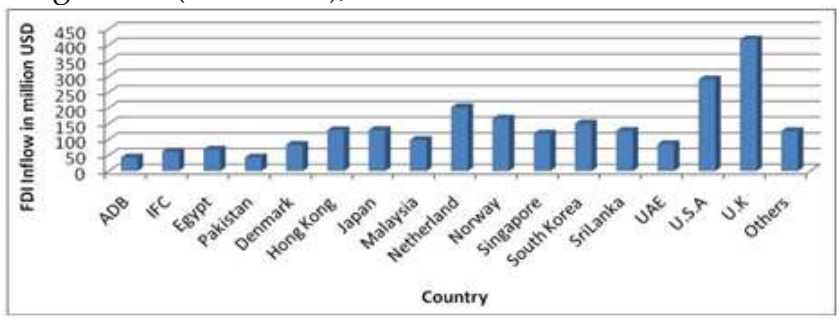

Figure 12: FDI Inflows (in million USD) by countries during 2001-2005.

Copyright @ 2014, Asian Business Consortium | ABR
Source: Survey Report, Statistics Department of Bangladesh Bank and Foreign Direct Investment in Bangladesh (1971-2010), Board of Investment.

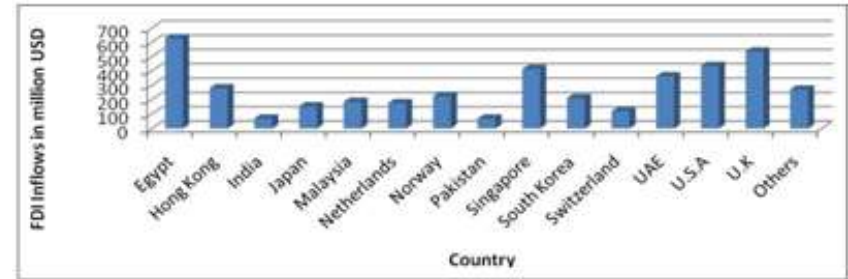

Figure 13: FDI Inflows (in million USD) by countries during 2006-2010.

Source: Survey Report, Statistics Department of Bangladesh Bank and Foreign Direct Investment in Bangladesh (1971-2010), Board of Investment.

Figures 3.5.3-3.5.5 showed how the ever changing nature of FDI inflows over the year. From the figures, it is clearly seen that developed country was highest investor during 19962005 but during 2006-2010 Middle East stood in the highest position. It revealed that there is a shift in investment regime. It reveals the importance for Bangladesh to maintain a continuous favorable business relation with developed countries for increasing their share of FDI in Bangladesh. The Asian countries should get more attention in terms of creating necessary investment climate. It is also important to continue warm relationship with Middle East countries as their significant share of FDI in recent years. Furthermore, Bangladesh must not lose the faith of $\mathrm{ADB}$ and IFC for FDI. They have a remarkable ranking in investing Bangladesh.

\section{Prospects \& Problems of FDI in BANGLADESH}

\section{Prospects of FDI}

Bangladesh has been promoting FDI for decades with the most liberal investment policy and incentive regime in South Asia. The Foreign Private Investment (Promotion and Protection) Act, 1980, ensures equal treatment for local and foreign Investors. This act also provides legal protection to foreign investment in Bangladesh against nationalization and expropriation. It also gives the guarantee of repatriation of capital and dividend.

Bangladesh has achieved a consistent GDP growth of over $5 \%$ in the last decade and never experienced a negative growth. Even Bangladesh sustained growth of over 5\% during the recent global economic crisis. In 2009 Bangladesh achieved a $5.9 \%$ GDP growth. Various necessary steps like generation of huge number of SMEs, success in micro credit and NGO activities, rapid spread of telecommunications services, record level of foreign remittances, acceleration of export earnings are taking the economy at a higher level of growth. Its investment friendly climate offers generous and attractive packages of incentives for foreign investors like 100\% ownership, tax and duty exemptions and others. Actually, Bangladesh has gained a higher ranking than many 
developing countries in terms of incentive package. A lot of additional fiscal incentives are offered to export oriented industries. The government has created Export processing zones (EPZs) to attract private investment. The government targets foreign investors to invest in EPZ.

The vision is that the unique opportunities in energy and power, infrastructures, manufacturing and knowledgebased sectors will attract substantial investment. Bangladesh has become a least cost producer in the world with various positive factors like industrious lowcost workforce, strategic location, regional connectivity and worldwide access, strong local market and growth, low cost of energy, proven export competitiveness, competitive incentives, export and economic zones, positive investment climate. Bangladesh is ranked 119th position globally and 4th in the SAARC region in the Ease of Doing Business Ranking by World Bank and IFC report entitled "Doing Business in 2010".

\section{Facilities and incentives for foreign investors}

FDI has been allowed in all sector of the economy except five industries - defense equipment, nuclear energy, forest plantation, security printing and railways.

The investors enjoy the following incentives for investing in Bangladesh -

a) 5 to 7 years corporate tax holiday for selected sectors.

b) Private power companies enjoy corporate income tax exemption for a period of 15 years.

c) Tax exemption on royalties, technical knowhow and technical assistance fees and facilities for their repatriation.

d) Tax exemption on foreign loans regarding interest.

e) Tax exemptions on capital gains from transfer of shares by the investing company.

f) Remittances of up to $50 \%$ of salaries of the foreigners employed in Bangladesh and facilities for repatriation of their savings and retirement benefits at the time of their return.

g) No restrictions on issuance of work permits to project related foreign nationals and employees.

h) Facilities for repatriation of invested capital, profits and dividends.

i) Provision of transfer of shares held by foreign shareholders to local investors.

j) Reinvestment of remittance dividends would be treated as new investment.

k) An investor can wind up on investment either through a decision of the AGM. Once a foreign investor completes the related formalities to exit the country, he or she can repatriate the sales proceeds after securing proper authorization from the Central bank.

Bangladesh makes no difference between foreign private investors and domestic investors regarding investment incentives or export and import policies. In Bangladesh foreign investors enjoy the access to domestic capital markets for working capital in the form of loans sanctioned from the commercial banks and development financial institutions. The foreign investors have been given the opportunity to have access to the services of the country's stock exchanges. Some export-oriented industries of the thrust sector are provided with the benefit of cash incentives, venture capital, and other investment friendly facilities.

The Board of Investment (BOI) of Bangladesh provides registration and other services. They also provide the procedures for FDI those have been simplified to attract FDI. Bangladesh Bank has prepared a sovereign and highly effective credit rating report. This should help to attract FDI as well as boost short-term borrowings for the country's private and public sectors. Country's image will be enhanced by this sound and sovereign credit rating report. It will certainly help local financial organizations to tap low-cost borrowings from foreign sources. The dependence on the London inter-bank offer rate will be definitely reduced. It also helps to obtain low-cost funds from foreign sources.

\section{Problems of FDI}

Although Bangladesh is trying to be as friendly as possible to FDI, she is facing some problems regarding investment from foreign sector. The FDI friendly policies of the government and a culture of hospitality to foreigners are very much positive to welcome FDI in Bangladesh. But it is a matter of concern that FDI records in the country in terms of the number of projects implemented as compared to those officially registered is frustrating. Only 72 FDI projects went into production in end of 1999 and 27 were in process of implementation of the 365 FDI projects registered during the year of 1996 - 1998, while the remaining 266 projects languished only as the file-cases.

The problems that have restricted FDI potentials in the country are as follows:

- Bureaucratic interference

- Irregularities in processing papers

- Overlapping administrative procedures

- Absence of a transparent system of formalities

- Continuity and prevent timely implementation of strategic, procedural, and even routine duties

- Frequent power failures

- Poor infrastructure support

- Labor unrest

- Political unrest

- Lack of professional personnel

- lack of commitment on the part of local investors

- Unexpected delays in selecting projects in studying feasibility

- Frequent changes in policies on import duties for raw materials, machinery, equipment etc. 


\section{IMPACT OF FDI INFLOW ON THE ECONOMY OF BANGLADESH}

\subsection{Impact of FDI inflow}

Now a daze Bangladesh is trying her best to attract foreign direct investment to boost up her economic condition. Bangladesh has liberalized a number of policies so that she can attract more foreign direct investment into the country. It is usually considered that foreign capital inflows can boost up domestic capital. It is believed that FDI accelerates economic activities and eventually causes economic growth. It increases employment opportunities. FDI brings highly productive resources into the recipient economy. This causes positive effects on the employment creation not only in the sectors that attract FDI inflows but also in the supportive domestic industries.

\subsection{Dependent Variables}

GDP: Gross domestic product (GDP) is the market value of all final goods and services produced within a country within a given period. There are many factors to accelerate GDP. It is assumed that the GDP is influenced by FDI Inflow. If the explanatory power of FDI Inflow, the independent variable is high over Gross domestic product (GDP), the dependent variable, the assumption will be proved.

EXPORT: There are many factors that can affect export. It is assumed that FDI Inflow is one of the prominent factors that influence the export. If the explanatory power of FDI inflow, the independent variable is high over export, the dependent variable, the assumption will be proved.

DOMESTIC INVESTMENT: There are many factors that can affect domestic investment. It is assumed that FDI Inflow is one of the prominent factors that influence the domestic investment through increasing competitiveness. If the explanatory power of FDI Inflow, the independent variable is high over domestic investment, the dependent variable, the assumption will be proved.

\subsection{INDEPENDENT VARIABLE FDI INFLOW}

FDI Inflow refers to the long-term investment in a foreign country. It consists of three components: equity capital, reinvested earnings and intra-company loans.

\subsection{MODEL SPECIFICATION}

To investigate the impact of FDI on GDP, it is assumed that$\mathrm{Y} 1=\mathrm{a}+\mathrm{b} 1 \mathrm{x} 1$

Where, $\mathrm{Y} 1=$ Gross Domestic Product in million USD, $\mathrm{a}=$ constant term,

$\mathrm{b} 1=$ Regression coefficients for the independent variable, $\mathrm{x} 1=$ FDI Inflow in million USD

Here, Y1 (i.e. GDP) is the dependent variable, while the $\mathrm{x} 1$ is the independent variable.

This test has been used to find out whether there is a relationship between dependent variable and the independent variable. Collected data has been processed and analyzed with the help of SPSS software.
To investigate the impact of FDI on export, it is assumed that$\mathrm{Y} 2=\mathrm{a}+\mathrm{b} 2 \mathrm{x} 2$

Where, $\mathrm{Y} 2=$ Export in million USD, $\mathrm{a}=$ constant term, $\mathrm{b} 2=$ Regression coefficients for the independent variable, $\mathrm{x} 2=$ FDI Inflow in million USD

Here, Y2 (i.e. Export) is the dependent variable, while the $x 2$ is the independent variable.

This test has been used to find out whether there is a relationship between dependent variable and the independent variable. Collected data has been processed and analyzed with the help of SPSS software.

To investigate the impact of FDI on Domestic investment, it is assumed that $-\mathrm{Y} 3=\mathrm{a}+\mathrm{b} 3 \times 3$

Where, $\mathrm{Y} 3=$ Domestic Investment in million USD, $\mathrm{a}=$ constant term,

b3 = Regression coefficients for the independent variable, $\mathrm{x} 3=$ FDI Inflow in million USD

Here, Y3 (i.e. Domestic Investment) is the dependent variable, while the $\mathrm{x} 3$ is the independent variable.

This test has been used to find out whether there is a relationship between dependent variable and the independent variable. Collected data has been processed and analyzed with the help of SPSS software.

5.5 Hypothesis of the study

H1: FDI Inflow has positive and significant impact on GDP. H2: FDI Inflow has positive and significant impact on export.

H3: FDI Inflow has positive and significant impact on domestic investment.

\section{RESULTS}

\section{Impact of FDI on GDP}

The following regression equation is found, $\mathrm{Y} 1=56987+158.757 \times$ FDII

Here $\mathrm{Y} 1$ = GDP in million USD

Table 1 Model Summary and ANOVA (F)

\begin{tabular}{|c|c|c|c|c|c|c|}
\hline & & Adjusted R & Std. Error of & F & Sig \\
\hline Model & R & R Square & Square & the Estimate & & \\
\hline & & & & & 17.451 & $.001(\mathrm{a})$ \\
\hline
\end{tabular}

a Predictors: (Constant), FDI Inflow in million USD $b$ Dependent Variable: GDP in million USD

The above table reveals that $\mathrm{F}$ value is significant at .001 level. This indicates that the variation caused by FDI Inflow in the GDP is significant. The value of Correlation Coefficient ( $R$ ) and Coefficient of Determination ( $R$ square and Adjusted R square) of the model are shown in the Table. The value of correlation coefficient is .757 and $R$ square is .573. These show that the independent variable under reference has high degree of correlation with GDP.

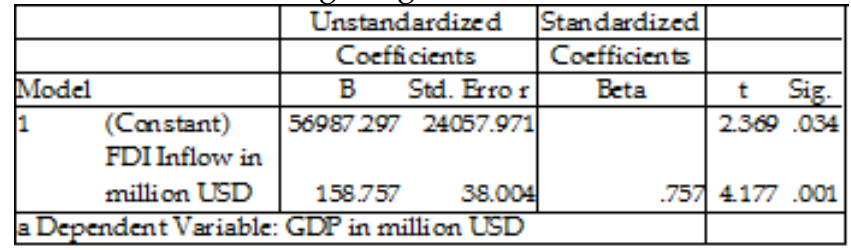


The above table presents regression coefficients that are obtained from the regression Model. This is observed that the independent variable FDI Inflow has exerted significant influence on GDP. As expected, FDI Inflow is found to have positive and significant relationship with GDP.

\section{Impact of FDI on Export}

The following regression equation is found,

$\mathrm{Y} 2=934.8+15.7 \times$ FDII

Here $\mathrm{Y} 2$ = Export in million USD

Table 3 Model Summary and ANOVA (F)

\begin{tabular}{|l|l|l|l|l|l|l|}
\hline Model & R & R Square & $\begin{array}{l}\text { Adjusted R } \\
\text { Square }\end{array}$ & $\begin{array}{l}\text { Std. Error of } \\
\text { the Estimate }\end{array}$ & F & Sig. \\
\hline 1 & .811(a) & .658 & .632 & 2941.73737 & 25.015 & $.000(a)$ \\
\hline
\end{tabular}

a Predictors: (Constant), FDI Inflow in million USD

b Dependent Variable: Export in million USD

The above table reveals that $\mathrm{F}$ value is significant at .000 levels. This indicates that the variation caused by FDI Inflow in the export is significant.

The value of Correlation Coefficient (R) and Coefficient of Determination ( $\mathrm{R}$ square and Adjusted $\mathrm{R}$ square) of the model are shown in the Table. The value of correlation coefficient is .811 and $\mathrm{R}$ square is .658. These show that FDI inflow, the independent variable under reference has high degree of correlation with export.

Table 4 Coefficients (a)

\begin{tabular}{|c|c|c|c|c|c|c|}
\hline & & \multicolumn{2}{|c|}{ Unstandardized } & Standardized & & \\
\hline & & \multicolumn{2}{|c|}{ Coefficients } & Coefficients & A & \\
\hline Model & & B & Std. Erro $\mathrm{r}$ & Beta & $\mathrm{t}$ & Sig. \\
\hline \multirow[t]{2}{*}{1} & (Constant) & 934.807 & 1988.528 & & .470 & .646 \\
\hline & $\begin{array}{l}\text { FDI Inflow in } \\
\text { million USD }\end{array}$ & 15.711 & 3.141 & .811 & 5.001 & .000 \\
\hline \multicolumn{5}{|c|}{ a Dependent Variable: Export in million USD } & & \\
\hline
\end{tabular}

The above table presents regression coefficients that are obtained from the regression Model. This is observed that the independent variable FDI Inflow has exerted significant influence on export.

As expected, FDI Inflow is found to have positive and significant relationship with export.

\section{Impact of FDI on Private investment}

The following regression equation is found,

$\mathrm{Y} 3=934.8+15.7 \times$ FDII

Here $\mathrm{Y} 3$ = Domestic investment in million USD

Table 5 Model Summary and ANOVA (F)

\begin{tabular}{|c|c|c|c|c|l|c|}
\hline & & & Adjusted R & Std. Erro r of & & \\
\hline Model & R & R Square & Square & the Estimate & F & Sig. \\
\hline 1 & $.750(\mathrm{a})$ & .563 & .529 & 3343.75800 & 16.728 & $.001(\mathrm{a})$ \\
\hline
\end{tabular}

a Predictors: (Constant), FDI Inflow in million USD

b Dependent Variable: Domestic Investment in million

USD

The above table reveals that $\mathrm{F}$ value is significant at .001 levels. This indicates that the variation caused by FDI Inflow in the Domestic Investment is significant. The value of Correlation Coefficient ( $R$ ) and Coefficient of Determination ( $R$ square and Adjusted $R$ square) of the model are shown in the Table. The value of correlation coefficient is .750 and $\mathrm{R}$ square is .563. This shows that
FDI inflow, the independent variable under reference has high degree of correlation with domestic investment. Table 6 Coefficients (a)

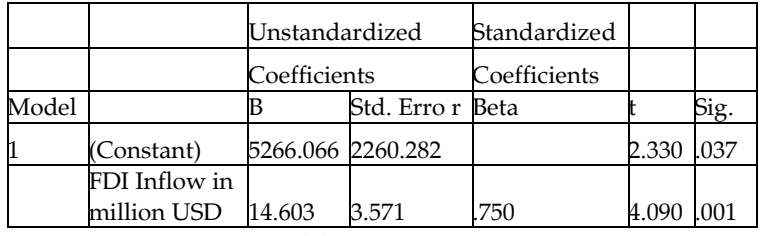

a Dependent Variable: Domestic Investment in milion USD

The above table presents regression coefficients that are obtained from the regression Model. This is observed that the independent variable FDI Inflow has exerted significant influence on domestic investment. As expected, FDI Inflow is found to have positive and significant relationship with domestic investment.

\section{Analysis}

The above regressions were tested for the period 19962010. The regression results suggest that the model is a good fit as indicated by the values of R2 and F statistics. It is observed that FDI Inflow has significant impact on GDP, export and private investment. The coefficients of the independent variable in each case suggest that FDI Inflow has positive and significant impact to accelerate GDP, export and private investment.

\section{GDP, GDP Growth, FDII/GDP and FDII/GDP Growth,} Export, Export/GDP and Domestic investment over time

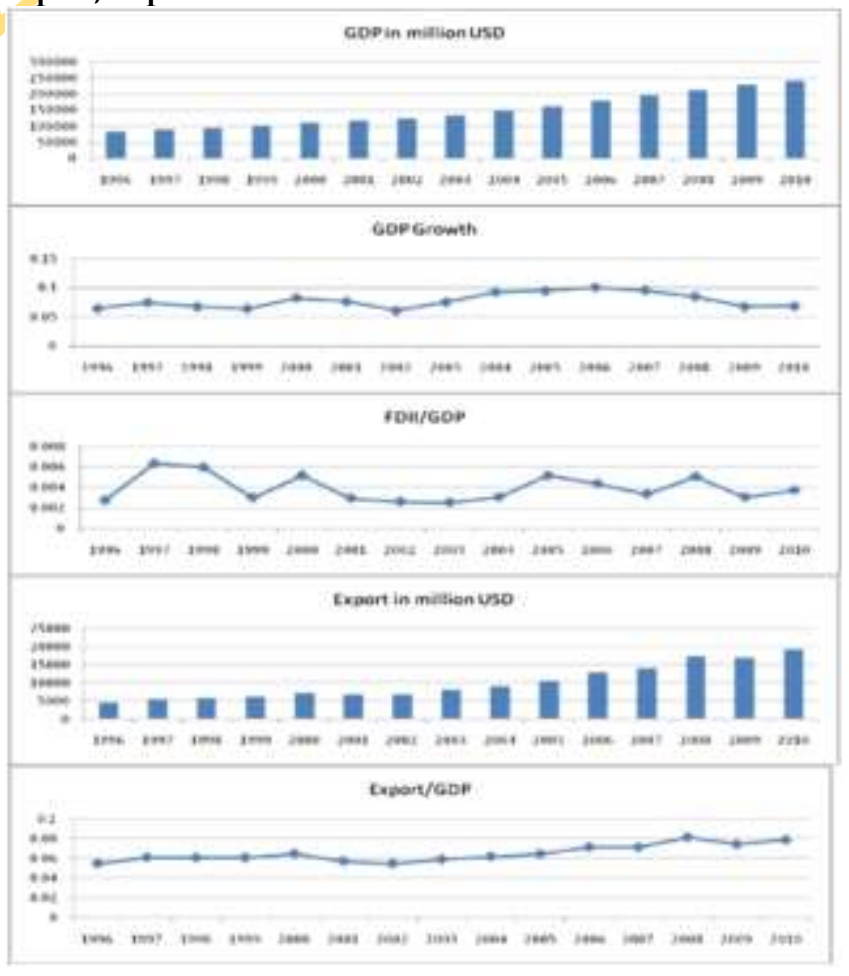




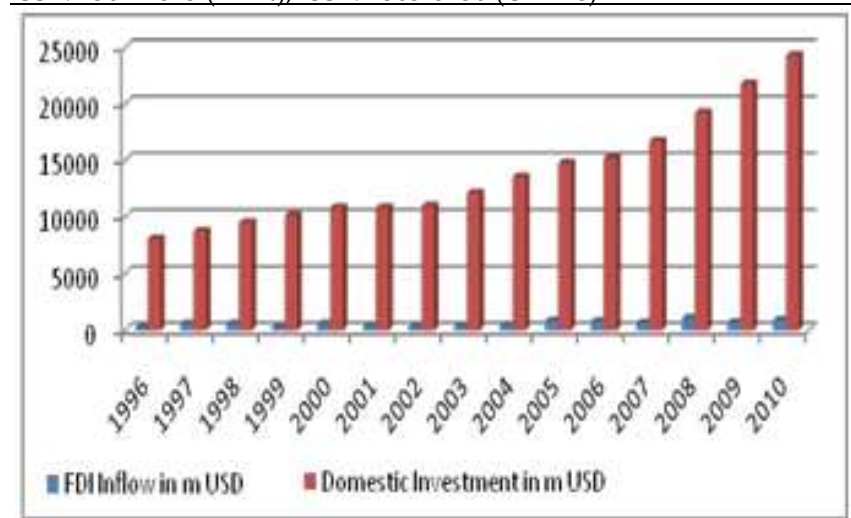

Figure 14 Trend of GDP, GDP Growth, FDII/GDP and FDII/GDP, Export, Export/GDP, FDI Inflow and Domestic investment over time

Source of data: Bangladesh Board of Investment (BOI)

The above graphs show that during 1996-2010, GDP has an increasing trend. GDP Growth fluctuates from $6.09 \%$ to $10.08 \%$ and FDII/GDP ratio lies between 0.003 and 0.006 . The mean and (standard deviation) of FDII/GDP ratio have been found 0.005 (0.001), $0.003(0.001)$ and $0.004(0.001)$ during 1996-2000, 2001-2005 and 2006-2010 respectively. The export/GDP ratio has an increasing trend over the period. This ratio stands between $5.46 \%$ and $8.17 \%$ during $2001-10$. The mean is $6.51 \%$ and standard deviation $0.86 \%$. The cumulative average growth rate during this period is $3.75 \%$. Domestic investment is increasing over time keeping pace with FDI inflow. The mean and (standard deviation) of domestic investment in million USD have been found 9,486 $(1,077), 12,476(1,693)$ and 19,476 (3,671) during 1996-2000, 2001-2005 and 2006-2010 respectively. Though FDI has positive and significant impact on GDP but FDI Inflow/GDP ratio is very small and it has no mentionable increasing trend. In order to accelerate GDP Growth, it is obvious to increase FDI Inflow.

\section{Conclusion \& Recommendations}

In Bangladesh FDI plays a very important role in achieving expected economic growth. FDI flows have been successful in increasing GDP. At the same time, FDI has also made a contribution in improving the income level of Bangladesh. FDI can ensure Bangladesh to realize higher growth by having the capabilities of using all the resources to the fullest potential. There is an increasing trend in foreign investment due to positive effect of the incentives provided and changes in our economic policies. FDI has positive correlation with GDP, export and private investment. In order to sustain the economic growth and continue the present status of FDI inflow, Bangladesh needs to maintain some effective steps. The administrative system of the country should be reformed through appropriate and effective measures. The bureaucracy needs to be reorganized. The control of bureaucracy should be minimized. Government should look into the law and order situation to ensure business friendly environment. A social consciousness is much more needed to ensure the rule of law and reduce the various effects of corruption. Both the government and private sector should be taken much more priority in this sector. They need to come ahead in investing in developing the infrastructure. Appropriate policy measures are needed to be developed so that private sector can run smoothly. If both public and the private sector work together in the same view of implementing economic reforms, Bangladesh will surely upgrade her position. Similarly, the further simplified custom clearance procedures can be very helpful in improving the present situation. In order to stimulate domestic and foreign investments, the privatization program can be initiated at large scale. It is important for a developing country like Bangladesh to modernize the laws relating to business and investment. It should be done focusing on international practices. The development of new industrial parks can play a very important role in attracting foreign investment in Bangladesh. The government may consider setting up new EPZs to encourage export oriented investors. Necessary steps should be taken to improve the image of the country abroad. An investment promotion agency needs to provide functions such as investment generation and policy advocacy. Bangladesh needs to strengthen economic and commercial diplomacy in attracting FDI in by rapid globalization and increasing competition. Bilateral relations with potential investor countries should be improved. Bangladesh should take effective steps in accelerating reform measures for banks, other financial institutions and capital market. A good governance and political stability should be ensured. Corporate governance will play a key role in enhancing the investment climate of Bangladesh. So we should implement corporate governance strongly in financial sector. The rate of corporate taxes is $40 \%$ for non- listed companies. It is one of the highest in Asia. This rate should be favorable for investors. Different ministries and organization needs to work in an integrated manner to successfully address issues regarding sectors. In future, the prospect of the Bangladesh economy would be affirmative if initiatives can be taken to consolidate the proposed reforms. Recently Bangladesh has taken steps to simplify various processes to encourage increased FDI. The government, total financial sector and foreign investors must work together to achieve the goal of making Bangladesh a progressive economy by the end of this decade.

\section{ACKNOWLEDGMENT}

At the outset, all praise be only to Allah, the Omnipotent to accept this effort and to consider it for His sake only without whose grace this work would have not been accomplished. I would like to acknowledge with thanks all the institutions and individuals who helped me by providing resources, efforts and intellectual capital that resulted in this paper and comments published in this volume. I owe my greatest debts $\mathcal{E}$ thanks to my beloved wife Mahbuba Anwar, for her truly extra ordinary patience and emotional support. Last, but not the least, for any sort of error and omission in this research, I hold myself fully responsible. 


\section{REFERENCES}

Agosin, Manuel R. and Mayer, Ricardo, 2000, 'Foreign Investment in Developing Countries: Does It Crowd In Domestic Investment?' UNCTAD Discussion Paper 146, Geneva.

Alfaro, L., Chanda, Kalemli-Ozcan, S., and Sayek, S., 2006, 'How do fore ign direct investments promote economic growth? Exploring the effects of financial markets on linkages', NBER Working Paper Series 12522: 1-58.

Alfaro, L., Chanda, Kalemli-Ozcan, S., and Sayek, S., 2006, 'How do fore ign direct investments promote economic growth? Exploring the effects of financial markets on linkages', NBER Working Paper Series 12522: 1-58.

Athukorala P. A W., 2003, 'The Impact of Foreign Direct Investment for Economic Growth: A Case Study in Sri Lanka' 9th International conference on Sri Lanka Studies, 28th- 30th November 2003, Matara, Sri Lanka, Full Paper Number 092.

Balamurali, N. and Bogahawatte, C., 2004, 'Foreign Direct Investment and Economic Growth in Sri Lanka, Sri Lankan Journal of Agricultural Economics', Vol. 6, No. 1, pp. 37-50.

Balasubramanyam, V.N., Salisu, M., and Sapsford, D., 1996, 'Foreign direct investments and growth in EP and IS countries', The Economic Journal Vol. 106, pp. 92-105

Bengoa, M., and Sanchez- Robles, B., 2003, 'Foreign direct investment, economic freedom and growth: new evidence from Latin America', European Journal of Political Economy 19, pp.529-545.

Bhavan T, Xu Changsheng, Zhong Chunping, 2011, 'Determinants and Growth Effect of FDI in South Asian Economies: Evidence from a Panel Data Analysis', International Business Research, Vol. 4, Issue 1, pp. 48-55.

Borensztein, E., De Gregorio, J., and Lee, J.W., 1998, 'How Doe s Foreign Direct Investments Affect Economic Growth?' Journal of International Economics Vol. 45.

Carkovic, Maria, and Levine, Ross., 2002, 'Does Foreign Direct Investment Accelerate Economic Growth?', University of Minnesota, Department of Finance, Working Paper.

Chowdhury, A., and Mavrotas, G., 2006, 'FDI and growth: What causes what?' The World Economy Vol. 29.

Johnson, A., 2006, The Effects of FDI Inflows on Host Country Economic Growth' CESIS Working Paper Series in Economics and Institutions of Innovation, Vol 58, pp. 1-57.

Kumar, N., and Pradhan, J.P., 2002, 'Foreign Direct Investment, Externalities and Economic Growth in developing Countries: Some Empirical Explorations and Implications for WTO Negotiations on Investment', RIS Discussion Papers 27/2002, New Delhi.
Lee Jung Wan, Baimukhamedova Gulzada S, Akhmetova Sharzada, 2009, The Effects of Foreign Direct Investment on Economic Growth of A Developing Country: From Kazakhstan', Allied Academies International Conference. Academy for Economics and Economic Education. Vol. 12, Issue. 2, pp. 22-27.

Levine, R., Loayza, N. \& Beck, T., 2000, 'Financial Intermediation and Growth: Causality and Causes', Journal of Monetary Economics, Vol. 46, pp.31-77.

Markusen, James R. \& Venables, Anthony J., 1997, ' Foreign Direct Investment as a Catalyst for Industrial Development', NBER Working Papers 6241, National Bureau of Economic Research, Inc.

Misztal, Piotr, 2010, 'Foreign Direct Investments, As a Factor for Economic Growth in Romania' Journal of Advanced Studies in Finance, Vol. 1, Issue. 1, pp. 72-82.

Mottaleb, K.A., 2007, Determinants of Foreign Direct Investment and Its Impact on Economic Growth in Developing Countries, MPRA Paper 9457, University Library of Munich.

Muhammad Azam, 2010, 'An Empirical Analysis of the Impacts of Exports and Foreign Direct Investment on Economic Growth in South Asia. Interdisciplinary' Journal of Contemporary Research in Business, Vol. 2, Issue. 7, pp 249-58.

Musila, J.W., and Sigue, P.S., 2006, 'Accelerating Foreign Direct Investment Flow to Africa: From Policy Statements to Successful Strategies, Manegerial Finance, 32(7), pp.577-593.

Quader, Syed Manzur, 2009, 'Foreign Direct Investment in Bangladesh: An Empirical Analysis on its Determinants and Impacts', Retrieved from http://mpra.ub.unimuenchen.de/26134/MPRA Paper No.26134.

Rehman Abdul, Orangzab, Raza Ali, 2011, 'Determinants of Foreign Direct investment and its impact on GDP Growth in Pakistan', Interdisciplinary Journal of Contemporary Research in Business Vol. 2, Issue. 9, pp. 198-205.

Rothgeb, John M., Jr, 1984, 'The Effects of Foreign Investment On Overall And Sectoral Growth In Third World States', Journal of Peace Research, Vol. 21, No. 1, pp. 5-15.

Teanravisitsagool, Pattama, 1998, 'Trade-off Between Foreign and Domestic Investment: Theoretical Analysis and Empirical Investigation for the Case of Thailand', Department of Economics, Carleton University.

Xiaohui L., Chang S. and P. Sinclair, 2009, 'Trade, Foreign Direct Investment and Economic Growth in Asian Economies', Applied Economics, Vol. 41, pp. 1603 - 1612

\section{CALL FOR PAPER}

American Journal of Trade and Policy (AJTP) is an open-access, peer-reviewed interdisciplinary journal which seeks articles from any broad theme of international trade. AJTP features reports on current developments in international trade as well as on related policy issues. The digital online version is published by AJTP, and the hard copy (print) version is published by Asian Business Consortium, USA

$$
\text { Website: WWw.ajtp.us }
$$

Engineering International (EI) is a peer-reviewed multidisciplinary international journal devoted to academic advanced research in engineering disciplines. It specializes in the publication of comparative thematic issues as well as individual research articles, review essays, and book reviews. Committed to disseminating rigorous scientific research to the widest possible audience, EI is fully and freely accessible on line. Published by Asian Business Consortium, USA. Website: WWW.j-ei.us

\section{Important!!!}

If the responses and the revised manuscript are not submitted by the deadline, submission is deemed to have been abandoned. The rejection of the manuscript will be conveyed to the Authors. 


\section{APPENDICES}

Appendices A: Year wise FDI Inflow, GDP, Export, Domestic Investment and Export

\begin{tabular}{|c|c|c|c|c|c|c|}
\hline Year & $\begin{array}{c}\text { FDI Inflow } \\
\text { in million USD }\end{array}$ & $\begin{array}{c}\text { GDP in } \\
\text { million USD }\end{array}$ & $\begin{array}{c}\text { Do mestic Investment } \\
\text { in million USD }\end{array}$ & $\begin{array}{c}\text { Expo rt in } \\
\text { Million USD }\end{array}$ & FDII/ GDP & Export/GDP \\
\hline 1996 & 231.61 & 84300 & 8130.40 & 4614.1 & 0.0027 & 0.0547 \\
\hline 1997 & 575.29 & 90600 & 8769.60 & 5527.2 & 0.0063 & 0.0610 \\
\hline 1998 & 576.46 & 96700 & 9538.10 & 5865.3 & 0.0060 & 0.0607 \\
\hline 1999 & 309.12 & 102900 & 10140.90 & 6235.9 & 0.0030 & 0.0606 \\
\hline 2000 & 578.64 & 111400 & 10850.00 & 7214.2 & 0.0052 & 0.0648 \\
\hline 2001 & 354.47 & 119900 & 10848.00 & 6836.9 & 0.0030 & 0.0570 \\
\hline 2002 & 335.47 & 127200 & 11011.50 & 6951 & 0.0026 & 0.0546 \\
\hline 2003 & 350.25 & 136800 & 12150.50 & 8061.8 & 0.0026 & 0.0589 \\
\hline 2004 & 460.4 & 149500 & 13587.60 & 9233.7 & 0.0031 & 0.0618 \\
\hline 2005 & 845.26 & 163700 & 14784.40 & 10551.4 & 0.0052 & 0.0645 \\
\hline 2006 & 792.48 & 180200 & 15259.00 & 12887.5 & 0.0044 & 0.0715 \\
\hline 2007 & 666.36 & 197500 & 16737.30 & 14091.1 & 0.0034 & 0.0713 \\
\hline 2008 & 1086.31 & 214300 & 19258.40 & 17497.6 & 0.0051 & 0.0817 \\
\hline 2009 & 700.16 & 228700 & 21778.90 & 17010.8 & 0.0031 & 0.0744 \\
\hline 2010 & 913.32 & 244300 & 24299.40 & 19315.85 & 0.0037 & 0.0791 \\
\hline
\end{tabular}

\section{Appendices B: FDI Inflows by Components}

(Figures in million USD)

\begin{tabular}{|l|c|c|c|c|}
\hline Year & Equity Capital & Reinvested earnings & Intra- company Loans & Total Inflows \\
\hline 1996 & 69.63 & 121.65 & 40.33 & 231.61 \\
\hline 1997 & 332.06 & 163.45 & 79.78 & 575.29 \\
\hline 1998 & 280.51 & 189.88 & 105.07 & 576.46 \\
\hline 1999 & 137.47 & 76.23 & 95.42 & 309.12 \\
\hline 2000 & 350.18 & 77.77 & 150.69 & 578.64 \\
\hline 2001 & 233.78 & 65.01 & 55.68 & 354.47 \\
\hline 2002 & 133.81 & 116.82 & 84.84 & 335.47 \\
\hline 2003 & 156.14 & 170.13 & 23.98 & 350.25 \\
\hline 2004 & 155.89 & 239.79 & 64.72 & 460.4 \\
\hline 2005 & 425.59 & 247.48 & 172.19 & 845.26 \\
\hline 2006 & 503.65 & 264.74 & 24.09 & 792.48 \\
\hline 2007 & 401.61 & 213.24 & 51.51 & 666.36 \\
\hline 2008 & 809.25 & 245.73 & 31.33 & 1086.31 \\
\hline 2009 & 218.55 & 364.94 & 116.67 & 700.16 \\
\hline 2010 & 519.98 & 364.62 & 28.72 & 913.32 \\
\hline
\end{tabular}

Appendices C: FDI Inflows by Areas (Figures in million USD)

\begin{tabular}{|c|c|c|c|}
\hline \multicolumn{4}{|c|}{ Area } \\
\hline Year & EPZ & Non-EPZ & Total \\
\hline 1996 & 42.31 & 189.3 & 231.61 \\
\hline 1997 & 69.25 & 506.04 & 575.29 \\
\hline 1998 & 88.31 & 488.15 & 576.46 \\
\hline 1999 & 154.43 & 154.69 & 309.12 \\
\hline 2000 & 81.2 & 497.44 & 578.64 \\
\hline 2001 & 56.06 & 298.41 & 354.47 \\
\hline 2002 & 87.53 & 247.94 & 335.47 \\
\hline 2003 & 59.31 & 290.94 & 350.25 \\
\hline 2004 & 42.68 & 417.72 & 460.4 \\
\hline 2005 & 110.82 & 734.44 & 845.26 \\
\hline 2006 & 71.03 & 721.44 & 792.48 \\
\hline 2007 & 105.44 & 560.93 & 666.36 \\
\hline 2008 & 118.55 & 967.76 & 1086.31 \\
\hline 2009 & 141.88 & 558.28 & 700.16 \\
\hline 2010 & 118.17 & 795.15 & 913.32 \\
\hline
\end{tabular}


Asian Business Review, Volume 4, Number 1/2014 (Issue 7)

ISSN 2304-2613 (Print); ISSN 2305-8730 (Online)

Appendices D.1: FDI Inflows by major Sectors (1996-2005) (Figures in million USD)

\begin{tabular}{|l|c|c|c|c|c|c|c|c|c|c|}
\hline Sectors & $\mathbf{1 9 9 6}$ & $\mathbf{1 9 9 7}$ & $\mathbf{1 9 9 8}$ & $\mathbf{1 9 9 9}$ & $\mathbf{2 0 0 0}$ & $\mathbf{2 0 0 1}$ & $\mathbf{2 0 0 2}$ & $\mathbf{2 0 0 3}$ & $\mathbf{2 0 0 4}$ & $\mathbf{2 0 0 5}$ \\
\hline Agriculture \& Fishing & 0.3 & 1.4 & 1.4 & 2.9 & 15.2 & 1.1 & 1.6 & 4.1 & 1.7 & 2.3 \\
\hline Power & 0.0 & 0.0 & 78.5 & 39.3 & 155.7 & 119.1 & 53.5 & 29.7 & 30.4 & 27.2 \\
\hline Gas \& Petroleum & 47.0 & 242.1 & 156.7 & 44.3 & 145.4 & 73.4 & 4.4 & 58.4 & 93.7 & 181.1 \\
\hline Textiles \& Wearing & 41.3 & 58.1 & 87.7 & 123.4 & 115.1 & 56.2 & 92.5 & 46.7 & 37.7 & 96.5 \\
\hline Chemicals \&Pharmaceuticals & 29.4 & 34.2 & 9.6 & 14.9 & 2.6 & 2.4 & 1.7 & 2.9 & 4.0 & 3.9 \\
\hline Metal \& Machinery Products & 0.5 & 0.8 & 0.5 & 1.3 & 0.6 & 0.0 & 0.3 & 0.1 & 0.7 & 0.1 \\
\hline Leather \& Leather Products & 5.3 & 3.6 & 4.3 & 3.1 & 0.6 & 0.2 & 0.0 & 1.3 & 0.4 & 0.7 \\
\hline Banking & 87.6 & 126.9 & 157.3 & 8.3 & 39.4 & 18.2 & 56.0 & 39.2 & 61.2 & 117.8 \\
\hline Insurance & 0.0 & 4.1 & 5.5 & 0.0 & 0.0 & 0.0 & 0.0 & 0.0 & 0.0 & 5.8 \\
\hline Telecommunication & 1.4 & 5.9 & 25.3 & 0.0 & 5.4 & 0.9 & 48.5 & 45.9 & 127.5 & 278.8 \\
\hline Computer Software \& IT & 1.5 & 2.9 & 0.1 & 0.4 & 0.2 & 0.0 & 0.0 & 0.3 & 0.0 & 0.0 \\
\hline
\end{tabular}

Appendices D.2: FDI Inflows by major Sectors (2006-10) (Figures in million USD)

\begin{tabular}{|l|c|c|c|c|c|}
\hline Sectors & $\mathbf{2 0 0 6}$ & $\mathbf{2 0 0 7}$ & $\mathbf{2 0 0 8}$ & $\mathbf{2 0 0 9}$ & $\mathbf{2 0 1 0}$ \\
\hline Agriculture \& Fishing & 1.3 & 7.3 & 14.4 & 11.8 & 13.6 \\
\hline Power & 21.1 & 25.8 & 27.8 & 30.9 & 38.5 \\
\hline Gas \& Petroleum & 187.1 & 190.2 & 73.3 & 20.3 & 53.6 \\
\hline Textiles \& Wearing & 70.1 & 102.3 & 126.4 & 134.0 & 145.2 \\
\hline Chemicals \& Pharmaceuticals & 5.2 & 4.2 & 3.9 & 10.4 & 6.3 \\
\hline Metal \& Machinery Products & 0.0 & 0.0 & 0.0 & 1.3 & 3.1 \\
\hline Leather \& Leather Products & 0.0 & 1.5 & 1.6 & 7.2 & 10.5 \\
\hline Banking & 117.7 & 80.0 & 141.8 & 142.6 & 163.1 \\
\hline Insurance & 6.4 & 7.3 & 4.6 & 10.4 & 16.7 \\
\hline Telecommunication & 346.5 & 201.9 & 641.4 & 250.1 & 359.8 \\
\hline Computer Software \& IT & 0.2 & 0.0 & 0.4 & 1.8 & 5.0 \\
\hline
\end{tabular}

Appendices E.1: FDI Inflows by Countries (1996-2005) (Figures in million USD)

\begin{tabular}{|l|c|c|c|c|c|c|c|c|c|c|}
\hline Country & $\mathbf{1 9 9 6}$ & $\mathbf{1 9 9 7}$ & $\mathbf{1 9 9 8}$ & $\mathbf{1 9 9 9}$ & $\mathbf{2 0 0 0}$ & $\mathbf{2 0 0 1}$ & $\mathbf{2 0 0 2}$ & $\mathbf{2 0 0 3}$ & $\mathbf{2 0 0 4}$ & $\mathbf{2 0 0 5}$ \\
\hline Australia & 55.08 & 81.25 & 128.5 & 0.07 & 1.54 & 0 & 0.01 & 0 & 0 & 0 \\
\hline China & 0 & 0.57 & 2.67 & 0.35 & 0.52 & 0.11 & 2.64 & 4.01 & 0.37 & 1.62 \\
\hline Den mark & 2.23 & 0 & 0.03 & 0.14 & 58.96 & 10.61 & 21.6 & 14 & 18.75 & 18.28 \\
\hline Egypt & 0 & 0 & 0 & 0 & 0 & 0 & 0 & 0 & 19.86 & 48.4 \\
\hline Hong Kong & 5.94 & 21.63 & 13.13 & 20.5 & 20.46 & 23.39 & 23.5 & 15.9 & 13.89 & 53.09 \\
\hline India & 1.01 & 1.7 & 1.66 & 0 & 8.5 & 2.08 & 4.3 & 3.63 & 6.8 & 2.67 \\
\hline Japan & 5.37 & 51.31 & 15.64 & 35 & 28.56 & 6.85 & 17.6 & 29.2 & 30.03 & 46.42 \\
\hline Malaysia & 0.08 & 6.12 & 5.02 & 2.92 & 7.96 & 0.45 & 13 & 13.4 & 38.99 & 33.07 \\
\hline Netherlands & 0.41 & 1.44 & 0.69 & 22.2 & 158.7 & 126.8 & 24.9 & 26.5 & 8.86 & 15.36 \\
\hline Norway & 0 & 0 & 23.71 & 3.31 & 0 & 0.84 & 30.4 & 22 & 59.64 & 53.48 \\
\hline Pakistan & 1.29 & 2.14 & 0.38 & 1.87 & 1 & 0.75 & 13.2 & 0.01 & 3.81 & 25.48 \\
\hline Saudi Arabia & 0 & 24.32 & 0 & 1.54 & 2.49 & 2.2 & 0 & 0 & 0 & 0.97 \\
\hline Singapore & 0.03 & 2.83 & 0.5 & 1.09 & 1.97 & 1.67 & 14.3 & 3.31 & 2.35 & 97.5 \\
\hline South Korea & 43.2 & 34.59 & 70.94 & 101 & 61.6 & 21.23 & 55.5 & 26 & 18.45 & 29.86 \\
\hline SriLanka & 0 & 0 & 0.82 & 0 & 0.07 & 0 & 0.13 & 2.23 & 3.44 & 4.06 \\
\hline Switzerland & 5.24 & 3.99 & 23.4 & 2.95 & 11.96 & 0.87 & 4.57 & 1.98 & 7.15 & 2.26 \\
\hline Taiwan & 0.02 & 7.27 & 0.54 & 3.37 & 2.7 & 0.27 & 0.33 & 2.03 & 1.28 & 11.38 \\
\hline UAE & 0.15 & 0.14 & 0.18 & 1.58 & 0 & 0.86 & 0.04 & 16.7 & 12.84 & 55.48 \\
\hline U.S.A & 14.39 & 67.64 & 232.9 & 66.9 & 29.34 & 30.85 & 24.5 & 32.1 & 61.76 & 141.8 \\
\hline U.K & 86.35 & 255.9 & 40.93 & 35.6 & 157.3 & 71.31 & 18.5 & 83.6 & 91.05 & 152.8 \\
\hline A.D.B & 0 & 0 & 0 & 0 & 2.1 & 0.32 & 0.17 & 0.43 & 29.51 & 12.67 \\
\hline I.F.C & 0.22 & 0.29 & 0 & 1.62 & 0.21 & 0.25 & 9.72 & 0.27 & 19.92 & 31.68 \\
\hline Others & 10.6 & 12.19 & 14.87 & 6.68 & 22.66 & 52.72 & 56.4 & 53.1 & 11.66 & 6.89 \\
\hline
\end{tabular}

Appendices E.2: FDI Inflows by Countries (2006-10) (Figures in million USD)

\begin{tabular}{|l|c|c|c|c|c|}
\hline Country & $\mathbf{2 0 0 6}$ & $\mathbf{2 0 0 7}$ & $\mathbf{2 0 0 8}$ & $\mathbf{2 0 0 9}$ & $\mathbf{2 0 1 0}$ \\
\hline Australia & 0 & 0 & 0 & 0.22 & 13.95 \\
\hline China & 0.92 & 0.48 & 4.5 & 3.24 & 8.66 \\
\hline Den mark & 15.38 & 8.99 & 1.91 & 9.09 & 5.91 \\
\hline Egypt & 105.36 & 75.17 & 373.4 & 72.71 & 3.01 \\
\hline Hong Kong & 47.43 & 55.45 & 39.85 & 75.6 & 63.84 \\
\hline India & 6.09 & 1.67 & 11.29 & 7.99 & 43.19 \\
\hline Japan & 22.79 & 36.61 & 57.15 & 17.47 & 21.79 \\
\hline Malaysia & 44.46 & 19.54 & 70.72 & 43.84 & 7.45 \\
\hline Netherlands & 13 & 18.67 & 31.67 & 49.62 & 64.92 \\
\hline Norway & 82.95 & 25.68 & 33.47 & 45.63 & 39.16 \\
\hline Pakistan & 5.14 & 3.49 & 12.51 & 30.14 & 18.88 \\
\hline Saudi Arabia & 0.52 & 1.73 & 2.66 & 2.62 & 11.91 \\
\hline Singapore & 35.89 & 10.68 & 32.28 & 19.12 & 317.19 \\
\hline South Korea & 53.86 & 27.68 & 44.64 & 46 & 40 \\
\hline SriLanka & 2.63 & 3.55 & 7.19 & 7.37 & 8.85 \\
\hline Switzerland & 2.8 & 13.39 & 69.25 & 29.06 & 5.89 \\
\hline Taiwan & 2.36 & 0.17 & 1.96 & 11.1 & 7.59 \\
\hline UAE & 88.02 & 83.27 & 102.2 & 67.08 & 24.5 \\
\hline U.S.A & 175.72 & 120.36 & 40.92 & 42.89 & 56.95 \\
\hline U.K & 70.47 & 142.55 & 130.57 & 88.08 & 105.68 \\
\hline A.D.B & 0 & 0 & 0 & 0 & 0 \\
\hline I.F.C & 0 & 0 & 0 & 0 & 0 \\
\hline Others & 16.69 & 17.23 & 18.17 & 31.29 & 44 \\
\hline
\end{tabular}

\section{ABR!!!}

"Speedy publication service, Online archives, Paperless, webbased peer review system, Open access policy, Indexing in world known citation databases, Global circulation, Broad international readership and authorship, Online submission system, Minimum publication charge" 